\title{
TÉCNICA DE OBTENÇÃO DE FILTRADO DE CULTURA DE Alternaria solani
}

\section{IÁRA V. GOMES-OLIVEIRA ${ }^{1} \&$ AIDA T. S. MATSUMURA ${ }^{2}$}

\author{
${ }^{1}$ Departamento de Zoologia e Genética, Instituto de Biologia, Universidade Federal de Pelotas, Campus Universitário, \\ Cx. Postal 354, CEP 96010-900, Pelotas, RS, e-mail: valquide@ ufpel.tche.br, ${ }^{2}$ Departamento de Fitossanidade, \\ Faculdade de Agronomia, Universidade Federal do Rio Grande do Sul, Avenida Bento Gonçalves, 7712,
}

Cx. Postal 776, CEP 91540-000, Porto Alegre, RS, e-mail: aida@ufrgs.br

(Aceito para publicação em 04/07/2000)

Autor para correspondência: Iára Valquide Gomes-Oliveira

\section{ABSTRACT \\ Technique to obtain of Alternaria solani culture filtrate}

This work was developed to adapt culture filtrates of Alternaria solani to be used in vitro selection of resistant potato. Three isolates of A. solani (I1 and I2) from Eldorado do Sul and Rio Pardo were used. Two liquid media, V8 and Czapek, were used to grow each of the fungal isolate, giving

Muitos pesquisadores selecionaram plantas resistentes a doenças usando métodos de seleção in vitro com pressão seletiva exercida por filtrados de cultura de patógenos (Behnke, Theor. Appl. Genet. 55: 69-71, 1979; Jin et al., Plant Dis. 80: 922-927, 1996). A obtenção de filtrados de cultura de Alternaria solani (Ell. \& Martin) Jones \& Grout. é simples, viável e pode facilitar os trabalhos de seleção de plantas de batata (Solanum tuberosum L.)resistentes ao patógeno. Este trabalho teve por objetivo a obtenção de filtrados de $A$. solani, para posterior utilização na seleção in vitro de plantas de batata resistentes a pinta preta.

Os isolados do fungo foram obtidos de folhas de batateiras com sintomas característicos de pinta preta, coletadas na Estação Experimental Agronômica da UFRGS, Eldorado do Sul / RS, das cultivares Baronesa (Isolado 1) e Trapeira (Isolado 2) e na localidade de Rincão del Rei, Rio Pardo / RS, da cultivar Baronesa (Isolado 3). Segmentos de folhas com 1 $\mathrm{cm}^{2}$ com sintomas, foram desinfestados e colocados em placas de Petri com meio BDA (batata-dextrose-ágar) acidificado com cinco gotas de ácido lático a $25 \%$ para cada $100 \mathrm{ml}$ de meio, e incubados em câmara de crescimento, com fotoperíodo de $12 \mathrm{~h}$ e temperatura de $25^{\circ} \mathrm{C}$.

O teste de patogenicidade foi feito em folhas destacadas de batateira sadia, cultivar Baronesa. Estas folhas foram desinfestadas com álcool diluído em água destilada na proporção de 1:1, solução de hipoclorito de sódio a $1 \%$ e enxaguadas em água destilada esterilizada. Em seguida, foram colocadas em placas de Petri, sobre suporte de vidro apoiado sobre três camadas de papel filtro umedecidas, e inoculadas por deposição de quatro a cinco gotas ( $50 \mu \mathrm{l}$ cada) de suspensão de conídios (2,4 x $10^{4}$ esporos / $\left.\mathrm{ml}\right)$ na superfície das mesmas. Após quatro dias de incubação a $25^{\circ} \mathrm{C}$ e $12 \mathrm{~h}$ luz, foi observada a presença ou ausência de lesões características produzidas por $A$. solani. six culture filtrates (I1 V8, I2V8, I3V8, I1Cz, I2Cz and I3Cz). Two sterilization forms, Millipore and autoclave were tested. There was no difference in these two sterilization forms. Tissue culture and toxic filtrates of $A$. solani have a potential to reduce the time in selection of resistant potato.

O micélio foi recuperado a partir de lesões e repicado em placas de Petri contendo meio BDA acidificado.

Para obter os filtrados de cultura de A. solani, foi induzido o crescimento do fungo em dois meios líquidos Czapek (Cz) e V8. Foram repicados dois segmentos de $1 \mathrm{~cm}^{2}$ de micélio do fungo crescido em meio V8 sólido para frascos com capacidade de $500 \mathrm{ml}$ contendo $150 \mathrm{ml}$ de meio líquido V8 ou Cz e incubados sob agitação orbital de $70 \mathrm{rpm}$ a $25^{\circ} \mathrm{C}$, por 20 dias. Estas culturas originaram seis filtrados de cultura de $A$. solani. Após o vigésimo dia de incubação, os meios líquidos foram passados por oito camadas de gaze, depositadas em funis de vidro, para erlenmeyers. Estes filtrados foram submetidos a novas filtragens, em papel filtro Whatman $\mathrm{n}^{\circ}$ 1 , até a obtenção de um líquido transparente, cujo $\mathrm{pH}$ foi ajustado para 5,5 com NaOH $1 \mathrm{~N}$. Os filtrados assim obtidos foram distribuídos em frascos coletores previamente esterilizados. Foram testadas duas formas de esterilização, por autoclavagem e por filtração em membranas com poros de $22 \mu \mathrm{m}$ de diâmetro. Nos relatos de seleção in vitro de plantas resistentes a doenças, a forma de esterilização usada para os filtrados de cultura de fungos tem sido através de membranas (Behnke, Theor. Appl. Genet. 55: 69-71, 1979; Jin et al., Plant Dis. 80: 922-927, 1996), o que aumenta o tempo de manipulação do material na preparação dos meios de cultura de tecidos. Estudos realizados mostraram que a esterilização dos filtrados de $A$. solani pelo sistema de membranas foi tão eficiente quanto aquele realizado por autoclavagem a $120{ }^{\circ} \mathrm{C}(1 \mathrm{~atm})$ por $20 \mathrm{~min}$. A facilidade da esterilização por autoclavagem somada à condição essencial de que este tipo de esterilização não tenha alterado o efeito tóxico dos filtrados recomenda com segurança este tipo de esterilização, o que diminui os custos dos trabalhos além de facilitar a preparação dos meios de cultura de tecidos com filtrado de cultura do fungo. 